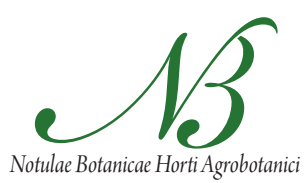

Cluj-Napoca

\title{
Some Fruit Characteristics of Cornelian Cherries (Cornus mas L.)
}

\author{
Sezai ERCISLI' ${ }^{1}$, Suzan O. YILMAZ², Jelena GADZE², Ahmed \\ DZUBUR ${ }^{4}$ Semina HADZIABULIC ${ }^{4}$, Jasmina ALIMAN ${ }^{4}$ \\ ${ }^{1}$ Ataturk University, Agricultural Faculty, Department of Horticulture, 25240 Erzurum, Turkey; sercisli@gmail.com \\ ${ }^{2}$ Sakarya University, Engineering Faculty, Department of Food Engineering, 54040 Sakarya-Turkey; suzanoz1@yahoo.com \\ ${ }^{3}$ Zagreb University, Agricultural Faculty, Department of Pomology, 1000 Zagreb, Croatia, jelena.gadze@gmail.com \\ ${ }^{4}$ Dzemal Bijedic University, Agro Mediterranean Faculty, 88104 Mostar-Bosnia and Herzegovina; ahmed.dzubur@unmo.ba
}

\begin{abstract}
This study was carried out on 13 local cornelian cherry (Cornus mas L.) genotypes grown in Yusufeli (Artvin) in Northeast Anatolia in Turkey. Cornelian cherry fruits from these 13 genotypes were harvested and analyzed during the ripening period in 2010. Some physical and chemical characteristics of cultivars were determined. Fruit weight and fruit flesh ratio of these genotypes ranged from 2.72 to $4.11 \mathrm{~g}$ and 79.08 to $89.99 \%$. Soluble solid content were determined the lowest as $13.7 \%$ and the highest as $18.6 \%$. The genotypes had vitamin C between 31 to $70 \mathrm{mg} / 100 \mathrm{~g}$ with average of $50 \mathrm{mg} / 100 \mathrm{~g}$. Total protein, cellulose, tannin and ash content of genotypes were determined between $0.75-2.18 \% ; 0.36-1.08 \% ; 0.57-1.28 \%$ and $0.51-1.13 \%$. The genotypes were found to be free of pest and diseases. The present study showed that there were enough variability among cornelian cherry genotypes grown in same ecological conditions of a small area and these genotypes could be important both to improve nutritional value through germplasm enhancement programmes and to use them in organic production.
\end{abstract}

Keywords: chemical content, dogwood, food properties, fruit traits, principal coordinate analysis

\section{Introduction}

Plant genetic resources are any material of plant, containing functional units of heredity of actual and potential value. Genetic resources generally at the local, national and international levels, play a critical role in the life of the people of most of the countries. They are very important for agriculture (specifically for breeding) and for preservation of the environment (Day, 1997; Swanson, 1996). The people and the communities depend on these resources for their economic, social and cultural well-being (Hanemann, 1988). Destruction of biological diversity threatens the life-support system of all humans by undermining the ecological processes that provide the ingredients for our food, medicine, shelter and livelihoods (Duvick, 1991).

The Coruh valley contain a wide reserve of biodiversity of fruit tree species that, over a period of several centuries. The valley is accepted one of the 35 hotspots for plant biodiversity in the world (IUCN, 2009). More recently the diffusion of new cultivars belongs to different fruit species originating from genetic improvement programs and dam constructions on the rivers resulted high risk on these valuable genetic resources in the valley. However, public interest in the safeguarding of biodiversity and the development of a new interest in genetic resources and their scientific, economic and cultural importance, inspired some non governmental actions aimed at the valorisation and conservation of these valuable materials.

Cornelian cherries (Cornus mas L.) are abundant in Coruh valley located in Northeastern Anatolia and recent years increasing attention has been paid by consumers to this fruits which had unusual flavors and qualities, and they are rich with antioxidants and anthocyanins (Ersoy et al., 2011; Seeram et al., 2002; Yilmaz et al., 2009a).

There are about 65 species of cornelian cherry (Cornus spp.) distributed primarily throughout the temperate regions of the northern hemisphere (Eyde, 1988). Most species used as ornamentals and only a few species are grown for their fruits. Among species Cornus mas is the most widespread because of its better fruit characteristics (Seeram et al., 2002).

The cultivation of cornelian cherry (Cornus mas L.) in the Caucasus and Central Asia has occurred for centuries. Fruits of this species mainly used for food, medicine, ornamental and honey plant (Mamedov and Craker, 2004). In these areas, Turkey is an important centre of cornelian cherries (Ercisli et al., 2007), especially northern Anatolia (Yilmaz et al., 2009b).

In Turkey, the cornelian cherries is widely used on account of its antioxidant, antiallergenic, antimicrobial and antihistaminic properties. Approximately 15.000 tons of cornelian cherry fruit is produced yearly in the country. The fruit is either consumed directly or processed into va- 
256

rious products such as fruit juice, jam, marmalade, pestil (a dried form of marmalade produced in the eastern part of Turkey), paste, and sherbet or is dried (Celik et al., 2006).

Turkey has a rich gene pool of cornelian cherry genotypes adapted to various local and regional conditions (Ercisli, 2004). In Turkey, the majority of cornelian cherry trees are propagated by seeds. In most regions, these are the smallest groups of trees $(5-10)$ which are in reproductive state and still 'communicate' between themselves (pollinate each other). They are to be found in the forest margins. There are also numerous single or isolated cornelian cherry trees whose 'communication' is disturbed by mechanical obstructions (buildings, forest) or by too long distances. Such trees grow on farm yards, or can often be seen growing on the grasslands and nearby paths as solitary trees (Yilmaz et al., 2009b).

During the last two decades, the native and semi-wild cornelian cherry plants have been disappearing rapidly. This cornelian cherry genetic erosion is probably even faster that we could imagine previously. It is urgent to determine and conserve cornelian cherry genetic resources for future use before it is lost forever. Therefore the general aim of the study was to contribute to the exploration, collection and conservation of the germplasm of the cornelian cherry.

\section{Materials and methods}

The study was conducted in Yusufeli districts in Northeast part of Turkey. A total 13 seed propagated cornelian cherry (Cornus mas L.) genotypes were preselected in 2010 according to their better yield and fruit chracteristics in natural growing places and were assessed in this research. The pomological analyses encompassed 50 random mature fruits per genotypes. Fruit weight (g), flesh ratio (\%), skin color $(\mathrm{a} / \mathrm{b}$ ratio), soluble solid content $(\%)$, vitamin C $(\mathrm{mg} / 100 \mathrm{~g})$, titratable acidity $(\%)$, total protein (\%), cellulose (\%), tannin (\%) and ash (\%) content were assessed.

Fruit weight was measured by using a digital balance with a sensitivity of $0.001 \mathrm{~g}$. Flesh ratio (\%) was counted considering fruit and seed weight. Fruit skin color (as a and $b$ value) was measured on the cheek area of 30 fruits (Minolta Chroma Meter CR-400, Minolta-Konica, Japan)

Flesh parts of fruit samples were used to assess the total soluble solids content (SSC), titratable acidity (TA), vitamin C, total protein, cellulose, tannin and ash. Soluble solid contents (SSC) were determined by extracting and mixing one drops of juice from the each fruit into a digital refractometer and displayed as \%. Vitamin C and titratable acidity were determined with the reflectometer set of Merck Co (Merck RQflex). Total protein quantity was calculated by multiplying the nitrogen content using Kjeldahl method by the coefficient 6.25 (AOAC, 1995). Cellulose quantity was determined according to the met- hod reported in AOAC (1995). Tannins and ash were also determined according to AOAC (1995) procedures.

The statistical analyses were carried out using SAS (SAS Inst., 2005). The pomological characteristics were subjected to principle component analysis (PCA) using the PRINCOMP procedure. The relationships were determined from a covariance matrix derived from standardized morphological and chemical characteristics means and the output data sets consisted of eigen-values, eigenvectors, and standardized principal component scores.

\section{Results and discussion}

In the present study, we found considerable variations in all traits searched among cornelian cherry genotypes at $\mathrm{p}<0.01$ level. The average values of searched parameters were given in Tab. 1.

Fruit weight and fruit flesh ratio of cornelian cherry genotypes ranged from $2.72 \mathrm{~g}$ ('YU-5') to $4.11 \mathrm{~g}$ ('YU-8') and $79.08 \%$ ('YU-8') to $89.99 \%$ ('YU-3') with an average of $3.27 \mathrm{~g}$ and $83.53 \%$, respectively (Tab. 1). Previous studies showed that fruit weight and fruit flesh ratio is one of the most variable characteristics of cornelian cherries grown in both Turkey and elsewhere. Fruit weight and fruit flesh ratio of cornelian cherry genotypes in Turkey were reported between 1.49-9.11 g (Demir and Kalyoncu, 2003; Karadeniz, 2002; Karadeniz et al., 2009; Yilmaz et al., 2009b) and 74-93\% (Karadeniz, 2002; Karadeniz et al., 2009; Yilmaz et al., 2009b), respectively. These values were reported between 3.42 and $8.00 \mathrm{~g}$ and 79.32 and $88.55 \%$ in Serbia (Bijelic et al., 2011; Ognjanov et al., 2009), 0.5 and $3.4 \mathrm{~g}$ in Slovakia (Brindza et al., 2009) and 5.0 and 8.0 $\mathrm{g}$ and 89 and $92 \%$ in Ukraina (Klimenko, 2004).

The $\mathrm{a} / \mathrm{b}$ color values of genotypes varied from 1.44 ('YU-11') and 2.70 ('YU-9'), respecitvely (Tab. 1). The $a / b$ values could be important for cornelian cherries to estimate both harvest time and also anthocyanin content. The $a / b$ values are effectively use in tomato to estimate harvest time. The increasing $\mathrm{a} / \mathrm{b}$ value indicate the increase of red color (Batu, 2004). The increase of $a / b$ values are also indicate higher anthocyanin content. Therefore we could say that the genotype 'YU-9' might have more red color and higher anthocyanin content than the others.

The SSC, vitamin C and titratable acidity values of cornelian cherry genotypes were found between $13.7 \%$ ('YU-2') and 18.6\% ('YU-4'); $31 \mathrm{mg} / 100 \mathrm{~g}$ ('YU-2') and $70 \mathrm{mg} / 100 \mathrm{~g}$ ('YU-9') and 1.32\% ('YU-4') and 2.08\% ('YU-11') with an average values of $15.4 \%, 50 \mathrm{mg} / 100$ g and $1.77 \%$ (Tab. 1). Previously SSC content of cornelian cherry genotypes was recorded as between 12.06 and 21.16\% (Ercisli et al., 2006; Karadeniz, 1995; Karadeniz et al., 2009; Ognjanov et al., 2009). Titratable acidity in cornelian cherry was also reported between $1.34-4.56 \%$ (Karadeniz et al., 2001; Karadeniz, 2002; Yalcinkaya and Eti, 2000). Vitamin C content of cornelian cherries was 
Tab. 1. Fruit characteristics of 13 pre selected cornelian cherry (Cornus mas L.) genotypes

\begin{tabular}{|c|c|c|c|c|c|c|c|c|c|c|}
\hline Genotypes & $\begin{array}{c}\text { Fruit } \\
\text { weight }(\mathrm{g})\end{array}$ & $\begin{array}{c}\text { Fruit flesh } \\
\text { ratio }(\%)\end{array}$ & $\begin{array}{l}\text { Fruit skin } \\
\text { color } \mathrm{a} / \mathrm{b}\end{array}$ & SSC (\%) & $\begin{array}{c}\text { Vit.C } \\
(\%)\end{array}$ & $\begin{array}{c}\text { T.Acid. } \\
(\%)\end{array}$ & $\begin{array}{c}\text { Protein } \\
(\%)\end{array}$ & $\begin{array}{c}\text { Cellul. } \\
(\%)\end{array}$ & $\begin{array}{c}\text { Tannins } \\
(\%)\end{array}$ & Ash (\%) \\
\hline 'YU-1' & $3.06 \mathrm{~cd}$ & $84.78 \mathrm{~cd}$ & $2.53 a$ & $14.8 \mathrm{e}$ & $39 \mathrm{f}$ & $1.51 \mathrm{e}$ & $1.07 \mathrm{~d}$ & $0.36 \mathrm{~h}$ & $1.04 b c$ & $0.51 \mathrm{~g}$ \\
\hline 'YU-2' & $3.80 \mathrm{~b}$ & $79.10 \mathrm{f}$ & $2.07 \mathrm{bc}$ & $13.7 \mathrm{f}$ & $31 \mathrm{~g}$ & $1.95 \mathrm{~b}$ & $0.75 f$ & $1.00 \mathrm{~b}$ & $0.76 \mathrm{ef}$ & $0.64 \mathrm{f}$ \\
\hline 'YU-3' & 2.91de & $89.99 a$ & $1.75 \mathrm{de}$ & $16.2 \mathrm{c}$ & $52 \mathrm{de}$ & $2.04 a b$ & $1.39 \mathrm{c}$ & $0.62 \mathrm{f}$ & $0.67 \mathrm{~g}$ & $0.86 \mathrm{de}$ \\
\hline 'YU-4' & $4.03 \mathrm{ab}$ & $85.95 b c$ & $1.77 \mathrm{~d}$ & $18.6 \mathrm{a}$ & $68 \mathrm{a}$ & $1.32 \mathrm{f}$ & $1.63 \mathrm{~b}$ & $0.76 \mathrm{de}$ & $0.58 \mathrm{~h}$ & $1.11 \mathrm{ab}$ \\
\hline 'YU-5' & $2.72 \mathrm{e}$ & $80.38 \mathrm{ef}$ & $2.02 b$ & $15.5 \mathrm{~d}$ & $31 \mathrm{~g}$ & $1.53 \mathrm{e}$ & $0.98 \mathrm{de}$ & $0.30 \mathrm{~h}$ & $1.11 \mathrm{~b}$ & $1.13 \mathrm{a}$ \\
\hline 'YU-6 & $3.24 \mathrm{c}$ & $81.06 \mathrm{e}$ & $1.95 \mathrm{c}$ & $13.9 \mathrm{f}$ & $46 e$ & $1.64 \mathrm{~cd}$ & $0.80 \mathrm{f}$ & $0.52 \mathrm{fg}$ & $1.28 \mathrm{a}$ & $1.03 \mathrm{bc}$ \\
\hline 'YU-7' & $2.92 \mathrm{de}$ & $86.48 b$ & $1.52 \mathrm{fg}$ & $14.6 \mathrm{e}$ & $58 \mathrm{bc}$ & $1.40 \mathrm{f}$ & $1.61 \mathrm{~b}$ & $1.08 \mathrm{a}$ & $1.03 b c$ & $0.89 \mathrm{~d}$ \\
\hline 'YU-8' & $4.11 \mathrm{a}$ & $79.08 \mathrm{f}$ & $1.98 \mathrm{c}$ & $15.8 \mathrm{~d}$ & $48 \mathrm{de}$ & $2.03 \mathrm{ab}$ & $2.07 \mathrm{a}$ & $0.83 \mathrm{~d}$ & $0.90 \mathrm{~d}$ & $0.85 \mathrm{de}$ \\
\hline 'YU-9' & $3.16 \mathrm{~cd}$ & $80.79 \mathrm{e}$ & $2.70 \mathrm{a}$ & $16.3 \mathrm{bc}$ & $70 \mathrm{a}$ & $2.13 a$ & $1.79 \mathrm{~b}$ & $0.73 e$ & $1.03 \mathrm{bc}$ & $0.80 \mathrm{e}$ \\
\hline 'YU-10' & $2.73 \mathrm{e}$ & $85.77 \mathrm{bc}$ & $1.58 \mathrm{efg}$ & $15.7 \mathrm{~d}$ & $59 \mathrm{~b}$ & $1.73 \mathrm{c}$ & $2.18 \mathrm{a}$ & $1.01 \mathrm{~b}$ & $0.69 \mathrm{fg}$ & $1.11 \mathrm{ab}$ \\
\hline 'YU-11' & $3.79 \mathrm{~b}$ & $89.79 a$ & $1.44 \mathrm{~g}$ & $16.6 \mathrm{~b}$ & $53 \mathrm{~cd}$ & $2.08 \mathrm{a}$ & $1.39 \mathrm{c}$ & $0.48 \mathrm{fg}$ & $0.57 \mathrm{~h}$ & $0.85 \mathrm{de}$ \\
\hline 'YU-12' & $3.16 \mathrm{~cd}$ & $83.29 \mathrm{~d}$ & $2.08 \mathrm{bc}$ & $15.7 \mathrm{~d}$ & $46 e$ & $1.60 \mathrm{de}$ & $2.04 \mathrm{a}$ & $0.91 \mathrm{c}$ & $0.79 \mathrm{e}$ & $1.02 \mathrm{c}$ \\
\hline 'YU-13' & $2.99 \mathrm{cde}$ & $79.54 \mathrm{ef}$ & $1.70 \mathrm{def}$ & $13.9 \mathrm{c}$ & $53 \mathrm{~cd}$ & $2.07 \mathrm{a}$ & $0.87 \mathrm{ef}$ & $0.82 \mathrm{~d}$ & $1.07 \mathrm{bc}$ & $0.84 \mathrm{de}$ \\
\hline Min. & 2.72 & 79.08 & 1.44 & 13.7 & 31 & 1.32 & 0.75 & 0.36 & 0.57 & 0.51 \\
\hline Max. & 4.11 & 89.99 & 2.70 & 18.6 & 70 & 2.08 & 2.18 & 1.08 & 1.28 & 1.13 \\
\hline Average & 3.27 & 83.53 & 1.93 & 15.4 & 50 & 1.77 & 1.42 & 0.72 & 0.89 & 89 \\
\hline
\end{tabular}

${ }^{*}$ Values in the same column with different lower-case letters are significantly different at $\mathrm{P}<0.01$

previously found between $14.8-193 \mathrm{mg} / 100 \mathrm{~g}$ (Brindza $e$ t al., 2009; Ercisli et al., 2006; Klimenko, 2004; Ognjanov et al., 2009; Rop et al., 2010; Yilmaz et al., 2009a). Burmistrov (1994) stated that vitamin C in cornelian cherry populations increased towards northern region in Ukraina and he found high variability among genotypes (36$122 \mathrm{mg} / 100 \mathrm{~g}$ )

We found vitamin $\mathrm{C}$ content lower than Klimenko (2004) and higher than Rop et al. (2010). Our vitamin C results were consistent with data of the other authors. The significant differences described above, were not surprising due to the possible genotypic and/or environment effects (Ercisli and Esitken, 2004; Ercisli and Orhan, 2008).

The total protein, cellulose, tannin and ash content of cornelian cherry fruits were found between $0.75 \%$ ('YU-

Tab. 2. Coefficients and eigenvalues for the first three principle components (PC) of PCA for cornelian cherry (Cornus mas L.) sampled from Turkey

\begin{tabular}{cccc}
\hline Variable & PC1 & PC2 & PC3 \\
\hline Fruit weight & 0,14 & 0,51 & $-0,17$ \\
\hline Flesh ratio & 0,35 & $-0,13$ & $-0,39$ \\
\hline a/b & $-0,29$ & 0,08 & $-0,12$ \\
\hline SSC & 0,44 & $-0,04$ & $-0,33$ \\
\hline Vitamin C & 0,38 & 0,00 & 0,20 \\
\hline Titratable Acidity & $-0,04$ & 0,58 & 0,05 \\
\hline Proteins & 0,40 & 0,02 & 0,29 \\
\hline Cellulose & 0,20 & 0,20 & 0,70 \\
\hline Tannins & $-0,42$ & $-0,28$ & 0,23 \\
\hline Ash & 0,24 & $-0,52$ & 0,17 \\
\hline Eigenvalue & 3,38 & 1,62 & 1,35 \\
\hline Proportion & 0,34 & 0,16 & 0,14 \\
\hline Cumulative & 0,34 & 0,50 & 0,63 \\
\hline
\end{tabular}

2') and 2.18\% ('YU-10'); $0.36 \%$ ('YU-1') and 1.08\% ('YU-7'), 0.57\% ('YU-11') and 1.28\% ('YU-6') and 0.51 $\%$ ('YU-1') and 1.13\% ('YU-5'), respectively. Brindza et al. (2009) reported protein content between 0.34-0.50 $\%$ in cornelian cherry in Slovakia. We did not found any literature related to cellulose content of cornelian cherry. The all plant originated horticultural foods are sources of dietary fiber that refers to the cell wall components in plants: namely, pectin, beta-glucans, hemicellulose, cellulose, lignin, fructans, and gums. The fiber content and composition, however, varies depending on the plant part harvested for food, fruit or vegetable species, maturity, and the growing environment of the plant.

Cornelian cherry fruits are very rich sources of tannin compared to the most of fruits. Traditionally tannins from cornelian cherry has been using in ethnomedicinal purposes in cornelian cherry growing countries (Baytop, 2004). In Ukraina, wild grown cornelian cherry genotypes in natural populations were contained average 2400 $\mathrm{mg} / 100 \mathrm{~g}$ tannin (Burmistrov, 1994).

The means of all traits were subjected to PCA (Fig. 1 ). The results indicated that the first three components showed $34 \%, 16 \%$ and $14 \%$ of the phenotypic variations, for a total of $64 \%$. The most important traits positively correlated were fruit weight, flesh ratio, SSC, Vitamin C, protein, cellulose with $\mathrm{PC} 1$ and ash. a/b ratio, acidity, tannin and ash were negatively correlated with PC1 (Tab. 2).

The accessions were plotted on three dimensions based on their PCA results (Fig. 1). The genotypes were easily separated from each other with enough diversity. Continuous seed propagation in the region for centuries had resulted in a number of local genotypes differing in most of fruit characteristics in the valley. These genotypes are unknown origin and represent rich diversity. 


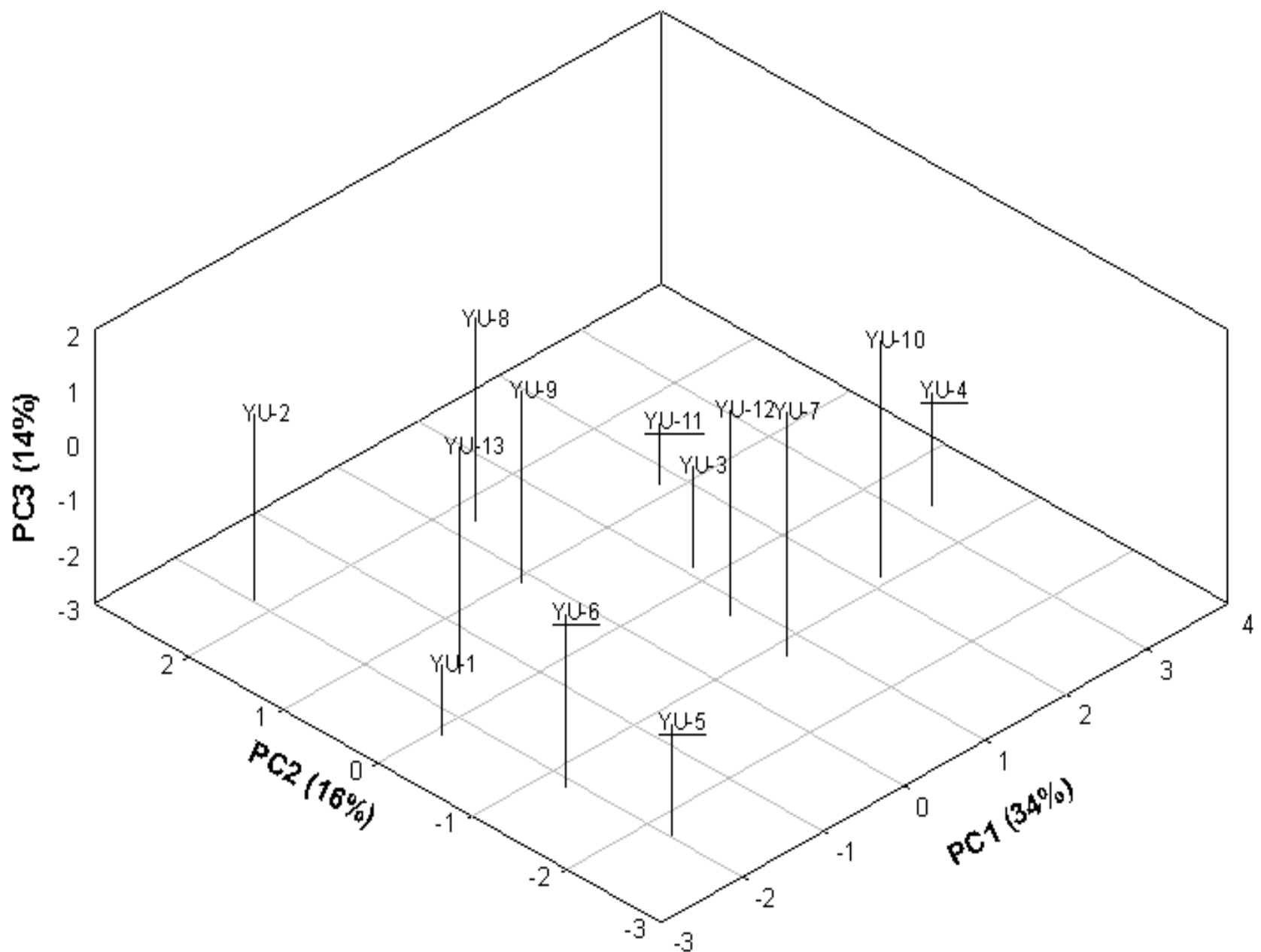

Fig. 1. PCA plot of the first three PCs depicting relationships among, Cornus mas genotypes sampled from Turkey

\section{Conclusions}

The research of cornelian cherry genetic resources even in a small area points to a great phenotypic diversity among the cornelian cherry genotypes that may have hidden important genes inside and they could be important for breeding better cornelian cherry cultivars by using them as parental material in future. This study also showed that cornelian cherry fruits are a rich source of nutrients for humans such as vitamins $\mathrm{C}$, dietary fiber, tannin etc. Currently this plant is less known and this new source can be potential as a functional food or value added ingredients in future in our dietary system.

\section{References}

AOAC (1995).Officials methods of analysis (16 thed.). VA, USA: Association of Official Analytical Chemist, Arlington.

Batu A (2004). Determination of acceptable firmness and colour values of tomatoes. J Food Eng 61:471-475.

Baytop T (2004). Therapy with medicinal plants in Turkey (Past and Present). Nobel Press, Istanbul. 353 p.
Bijelic S, Golosin B, Todorovic JN, Cerovic S (2010). Morphological characteristics of best cornelian cherry (Cornus mas L.) genotypes selected in Serbia. Genet. Resour. Crop Evol. (in press, DOI 10.1007/s10722-010-9612-2).

Brindza P, Brindza J, Tóth D, Klimenko SV, Grigorieva O (2009). Biological and commercial characteristics of cornelian cherry (Cornus mas L.) population in the Gemer region of Slovakia. Acta Hortic 818:85-94.

Burmistrov LA (1994). Underexploited Fruits and Nuts of Russia. In: WANATCA Yearbook West Australian Nut and Tree Crops Association 18:3-20.

Celik S, Bakirci I, Sat IG (2006). Physicochemical and organoleptic properties of yogurt with cornelian cherry paste. Int J Food Prop 9:401-408.

Day PR (1997). Biodiversity and the Equitable Use of the World's Genetic Resources. In: Hoagland KE, Rossman AY (Eds.). Global Genetic Resources: Access, Ownership and Intellectual Property Rights. Beltsville Symposia in Agricultural Research. Washington, DC: The Association of Systematics Collections. 
Demir F, Kalyoncu IH (2003) Some nutritional, pomological and physical properties. J Food Eng 60:335-341.

Duvick DN (1991). Industry and Its Role in Plant Diversity, Forum for Applied Research and Public Policy 6(3):90-94.

Ercisli S (2004). A short review of the fruit germplasm resources of Turkey. Genet Resour Crop Evol 51:419-435.

Ercisli S, Esitken A ( 2004). Fruit characteristics of native rose hip (Rosa spp.) selections from the Erzurum province of Turkey. New Zeal. J Crop Hort 32:51-53.

Ercisli S, Orhan E. Esitken A (2006). Genetic diversity in fruit quality traits in cornelian cherry (Cornus mas L.). Asian J Chem 18(1):650-654.

Ercisli S, Orhan E, Esitken A, Yildirim N, Agar G (2007). Relationships among some cornelian cherry genotypes (Cornus mas L.) based on RAPD analysis. Genet Res Crop Evol 55(4):613-618.

ErcisliS, Orhan E (2008). Some physico-chemical characteristics of black mulberry (Morusnigra L.) genotypes from Northeast Anatolia region of Turkey. Sci Hortic 116:41-46

Ersoy N, Bagci Y, Gok V (2011). Antioxidant properties of 12 cornelian cherry fruit types (Cornus mas L.) selected from Turkey. Sci Res Essays 6(1):98-102.

Eyde RH (1988) Comprehending Cornus: Puzzles and progress in the systematics of the dogwoods. Bot Rev 54:233-251.

Hanemann WM (1988). Economics and the Preservation of Biodiversity. In: Wilson EO (Ed.). Biodiversity. Washington, DC: National Academy Press.

IUCN (2009). International Union for Conservation of Nature. www.iucn.org.

Karadeniz T (1995). A study on the selection of native cornelian cherries grown in Gorele district in Turkey. Bahce 24(12):36-44.

Karadeniz T, Kalkisim O, Baltaci C (2001). The investigation on pomological characteristics of cornelian cherry (Cornus mas L.) grown in Trabzon. Proceeding $1^{\text {st }}$ National Stone Fruits Symposium, Yalova, pp. 307-311, September 25-28.

Karadeniz T (2002). Selection of native cornelian cherries grown in Turkey. J Amer Pom Soc 56(3):164-167.
Karadeniz T, Deligoz H, Corumlu MS, Senyurt M, Bak T (2009). Selection of native cornelian cherries grown in Çorum (Turkey). Acta Hort 825:83-88.

Klimenko S (2004). The cornelian cherry (Cornus mas L.)Collection, preservation and utilization of genetic resources. J Fruit Ornam Plant Res (Spec Ed) 12:93-98.

Mamedov N, Craker LE (2002). Cornelian cherry: a prospective source for phytomedicine. Acta Hort 629: 83-86.

Ognjanov V, Cerović S, Todorović J, Jaćimović V, Gološin B, Bijelić S, Vračević B (2009). Selection and utilization of table cornelian cherry (Cornus mas L.). Acta Hort 814:121-124.

Rop O, Mlcek J, Kramarova D, Jurikova T (2010). Selected cultivars of cornelian cherry (Cornus mas L.) as a new food source for human nutrition. Afr J Biotechnol 9(8):2051210.

SAS Institute. (2005). SAS Online Doc., Version 8. SAS Inst., Cary, NC, USA.

Seeram N, Schutzki R, Chandra R, Nair MG (2002). Characterization, quantification, and bioactivities of anthocyanins in Cornus species. J Agr Food Chem 50:25192523.

Swanson T (1996). Global Values of Biological Diversity: The Public Interest in the Conservation of Plant Genetic Resources of Agriculture. Plant Genetic Resources Newsletter No. 105. Rome: International Plant Genetic Resources Institute.

Yalcinkaya E, Eti S (2000). Cornelian cherry types selected in west Black Sea Region. www.age.edu.tr fitekno.

Yilmaz KU, Ercisli E, Zengin Y, Sengul M, Kafkas EY (2009a). Preliminary characterisation of cornelian cherry (Cornus mas L.) genotypes for their physico-chemical properties. Food Chem 114:408-412.

Yilmaz KU, Zengin Y, Ercisli S, Orhan E, Yalcinkaya E, Taner O, Erdogan A (2009). Biodiversity, ex-situ conservation and characterization of cornelian cherry (Cornus mas L.) genotypes in Turkey. Biotechno Biotec Eq 23(1):11431149. 